\title{
LANDSCAPING FOR PASSIVE SECURITY AND ADAPTATION TO CLIMATE IN CHURCH ENVIRONMENT, NIGER STATE, NIGERIA
}

\author{
O. F. Adedayo ${ }^{1,}$, , D. Ailoyafen ${ }^{2}$ and O. A. Adebayo ${ }^{3}$ \\ 1,2,3 Department of Architecture, Federal University of TeChnology, MinNA, Niger State. NiGERIA \\ E-mail addresses: 1arcadedayo@gmail.com, 2 emmado004@gmail.com, 3 toyin4biola@yahoo.com
}

\begin{abstract}
Nigeria is faced with several risks ranging from problems of climate change to security challenges and this is not limited to a specific aspect of the built environment as all buildings and environment are affected. The places of worship are greatly affected in terms of security which affects the disposition of Christians during worship at churches. Many of the studied churches were seen to have made use of landscape elements but these were not placed with the aim of using them to deter intrusion as in the case of security but rather for beautifying the church. The challenge for architects and church administrator is how to cope with challenges of security and climate change. This paper examines landscaping as a catalyst for deterring intrusion of threats passively and enhancing climate adaptation in church environment in Nigeria. The research method adopted for this study is the descriptive survey method by collecting qualitative and quantitative data. The results were analyzed using descriptive tools in SPSS and are presented in tables and charts while the pictures are presented in plates. The study reveals that it is possible to achieve passive security and solve some climatic challenges in church environment using soft landscape elements. The paper is concluded by determining the aspects of the building where the architect can infuse the specific landscape elements to achieve the aim of the paper. It further states the type of landscape elements that could be used to achieve the aim of the study hence developing a responsive building design scheme.
\end{abstract}

Keywords: Adaptation, Building, Climate change, Security, Soft landscaping.

\section{INTRODUCTION}

Climate change manifestations are wide ranging and irrefutable which are at least part of the result of human activities within their environment. Climate change is recognized as one of the greatest and most serious environmental challenges the world is confronted with in the $21^{\text {st }}$ century to the point that the global warming and climate changes issues top the agenda at global level [1]. It is widely believed that these changes could continue regardless of future greenhouse gas emissions because of the cumulative impacts of the emission that have arisen since the outset of industrialization. Most countries of the world today are experiencing extreme weather conditions and climate change associated natural disasters which scientists have concluded to be induced mostly by the activities of man [2]. High frequency of formation of cyclonic storm surges, high density rainfall along with changing precipitation patterns and prolonged droughts, hurricanes along with related landslides and wildfires are some of the extreme weather events in various parts of the world [3]. It was concluded by [3] that:
- $\mathrm{CO}_{2}$ levels are at their highest for 650,000 years

- Climate change is unequivocally happening

- There is a $90 \%$ chance that this is the result of human activity

- Man has 10-15 years left to put in place serious measures to start reducing emissions

It was observed by [4] that climate change is increasingly being called a security problem because there is concern that climate change may increase the risk of violent conflict. It believed that the issue of human security in developing countries could be greatly affected by climate change because of the reducing access to natural resources which is a requirement for survival and sustainability of the livelihoods of the people that is affected by the climate change being experienced. Nigeria, like other developing countries, which is a low emitter of energy is made to adapt to the expected impacts of the anticipated climate change [5] posing a threat to the country. Not only is Nigeria faced with the challenge of climate change but also other security challenges. 
Security has to do with freedom from danger, anxiety and fear; a situation that shows that a country is not exposed to sabotage or external attack [6, 7] is what defines security as a degree of protection to safeguard a country, group of people, person and properties from danger, destruction, attack and crime. Insecurity concept connotes different things ranging from danger, hazard, uncertainty, lack of protection to lack of safety. According to [8] insecurity is a state of fear or anxiety due to absence or lack of protection. According to [9] insecurity has two perspectives which included the state of a subject or item being subject to threat or danger which could cause dangers to the inhabitants or users of the building or structure while it also considered insecurity as a psychological state of being exposed to risk and anticipation of misfortune. It implies that the people that could be affected by insecurity oftentimes are not only uncertain or unaware of what would happen but they are also vulnerable to the threats and dangers when they occur. For this paper, insecurity is defined as the breach of peace and security regardless of the cause or source which contributes to conflicts that leads to the loss of lives and properties. The concept of security is related to the concept of safety, continuity and reliability. Security takes into consideration the actions of people planning to cause an attack. According to [10], building security is the degree to which a building, its facilities and users are protected from a potential threat that can cause any form of damage to the building and its users. Building security is beyond installing high technology electronic systems in a building to identify intruders but it is first of all a process of planning and designing from the concept stage how to hinder or delay attacks.

In Nigeria today, terrorism has become a fundamental source of insecurity with primary base generally located in religious fanaticism and intolerance in Northern Nigeria [9]. The effect of terrorist activities such as suicide bombings, kidnappings, destruction of lives, public infrastructure, private and entrepreneurial investments, the climate of fear, panic and confusion and a heated and ungovernable polity has continued to make Nigeria an unsuitable bride for foreign investments. This not only poses a threat to the budding democracy in place, it also may endanger efforts to achieve industrial development in the country. To face this challenge headlong, a multi-stakeholder imperative has become inevitable. Public places like churches, mosques, markets and other places of large gatherings have been the target of terrorists. Nonetheless the threats, churches and other public buildings can be planned in such a manner as to tackle the challenges of insecurity by the implementation of security design strategies. Having viewed the challenges, this research is aimed at finding out how landscape can be used to aid passive security design and at the same time be a means of adapting to the climate change in Minna, Niger state.

\subsection{Climate Change in Nigeria}

Climate change is considered as an array of changes that affect both world and regional climate as measured by such things as average temperature and rainfall, or an alteration in frequency of extreme weather conditions. This variation may be caused by both natural processes and human activity. Human activities have been has been considered as a major contributor towards climate change which has resulted in increased of greenhouse gases and widespread deforestation [11]. Nature in itself was made to take care of balancing the ecosystem in a suitable manner but that is without the effects of human activities. Therefore for the existence of man to continue on the earth surface, man must, in wisdom, utilize the natural resources in the most prudent and sustainable manner. The issue of global climate change due to the greenhouse effects such as global warming and sea level rise have been a major discourse in many scientific gatherings and the effects are felt in different forms of which flooding is one Developing countries like Nigeria contribute to the greenhouse emissions, though insignificantly as compared to the contribution of the developed countries [12]. Climate change and sea level rise would compound the serious problems of sustainability of the environment and management of resources, as well as the serious problems in population consumption patterns and characteristics in many parts of Africa and other developing countries [13]. The construction of buildings of which churches are part of also share part of the problems associated with climate change with regards to the environment surrounding the structure.

Developing countries such as Nigeria are believed not to be prepared for the evident impacts of global warming, the evidence of global warm is readily available in the country. The country has been lucky not to have experienced major climate-change-induced natural disasters, however the type of disaster experienced in Nigeria particularly in the urban areas are often perceived as man-made. The very hot weather conditions and high precipitations which have led to flooding, ruining crops in parts of the country creating food scarcity, the latest being Jigawa State; gully erosion has sacked many communities especially in Edo and Anambra States; as a result of persistent drought, the Lake Chad has almost dried up, while there had been persistent desert encroachment in the north [11].

\subsection{Adaptation of Man to Climate Change}

Adaptation simply refers to the different measures that should be taken to reduce the adverse impact of global 
warming on human life and the environment of which the buildings inhabited by humans. Examples of the adaptation methods include: changing the cropping patterns; stopping further development on wetlands, flood plains, and close to sea level; developing crops that are resistant to drought, heat and salt; strengthening public health and environmental engineering defense against diseases; designing and building new water projects for flood control and drought management; construction of dykes and storm surge barrier against sea level rise $[14,15]$. On the other hand, adaptation involves coping with climatic change, taking measures to reduce the negative effects, or exploit the positive ones by making appropriate adjustments. Adapting landscapes in the built-up areas and buildings to the changes is an urgent challenge for all those that have a role to play in the management of the built and natural environment [16].

\subsection{Insecurity in Nigeria}

One of the most fundamental source of insecurity in Nigeria today is terrorism which has its primary sources of support generally situated in religious fanaticism and intolerance particularly in Islam dominated states in Nigeria [9]. Terrorism which is a global phenomenon where no one is safe was defined by [17] as "the premeditated use or threat of use of violence by an individual or group to cause fear, destruction or death, especially against unarmed targets, property or infrastructure in a state, intended to compel those in authority to respond to the demands and expectations of the individual or group behind such violent acts".

Nigeria like many other countries has witnessed great level of insecurity in recent time particularly in the Northern part of the country [18]. This is evident with the amount of money allocated to security matters in the national budget to security. According to [19] a renowned expert on church safety, security and legal matters, "Most churches are safe places. While incidents of shootings on church property are shocking, they are rare. But because of the "open access" policy of most churches, they remain easy targets for violent acts. While such acts cannot be prevented, there are steps that church leaders can take to manage the risk." In order to reduce the incidence of crime, the Federal Government has embarked on criminalization of terrorism by passing the Anti-Terrorism Act in 2011, installation of ComputerBased Closed Circuit Television Cameras (CCTV), in some parts of the country, enhancement of surveillance as well as investigation of criminal related offences, heightening of physical security measures around the country aimed at deterring or disrupting potential attacks, strengthening of security agencies through the provision of security facilities and the development and broadcast of security tips in mass media [20,21]. Notwithstanding these efforts, the insecurity state in some part of the Nigeria is still high and seems insurmountable [22]. The need for security in church buildings is becoming more relevant than ever as a result of the increasing number of attacks experienced. The primary goal of a security design approach is to minimize the loss of life of the building's occupants. The most effective way to achieve this goal is with a comprehensive and coordinated, multidisciplinary approach to address security in the earliest phases of site selection and/or the design process [23]. Table 1 shows churches that were attacked in the Northern part of Nigeria between 2011 and 2012 and the number of casualties recorded. From Table 1, it would be observed that many lives were lost as a result of the various attacks on the mentioned churches; people sustained various degrees of injuries as well as assets lost. From the states affected, Madalla which is in Niger state was also affected. Madalla which is a busy and large settlement within Niger state was one of the targeted churches having the highest death record. Plate 1 show that the car was detonated very close to the church building and as such had great impact on the building and the worshippers in it. It would be advised that the state capital of Niger state, Minna should put in place measures which can help to hinder the intrusion of terrorists thereby preventing their attacks or reducing the effects of their attacks.

Table 1: List of Major Attacks on Churches in Northern Nigeria from 2011-2012

\begin{tabular}{|c|c|c|c|c|}
\hline S/No & Date of attack & State & Location of attack & Impact \\
\hline 1 & $25^{\text {th }}$ Dec, 2011 & NIGER & $\begin{array}{l}\text { Christmas Day Bombing in Madalla } \\
\text { Christ Apostolic Church was attacked }\end{array}$ & 50 people Killed \\
\hline 2 & $6^{\text {th }} \operatorname{Jan}, 2012$ & ADAMAWA & $\begin{array}{l}\text { and Igbo people were also killed in Mubi } \\
\text { in the same state }\end{array}$ & 37 people killed \\
\hline 3 & $8^{\text {th }}$ April, 2012 & KADUNA & Easter Day Church Bombing & 38 people Killed \\
\hline 4 & $17^{\text {th }}$ Jun, 2012 & KADUNA & Multiple attacks on churches & $\begin{array}{l}12 \text { people killed and } 80 \\
\text { injured }\end{array}$ \\
\hline 5 & 7th August, 2012 & KOGI & Deeper Life Church attack & 19 people killed \\
\hline
\end{tabular}

Source: Adapted from [22] 


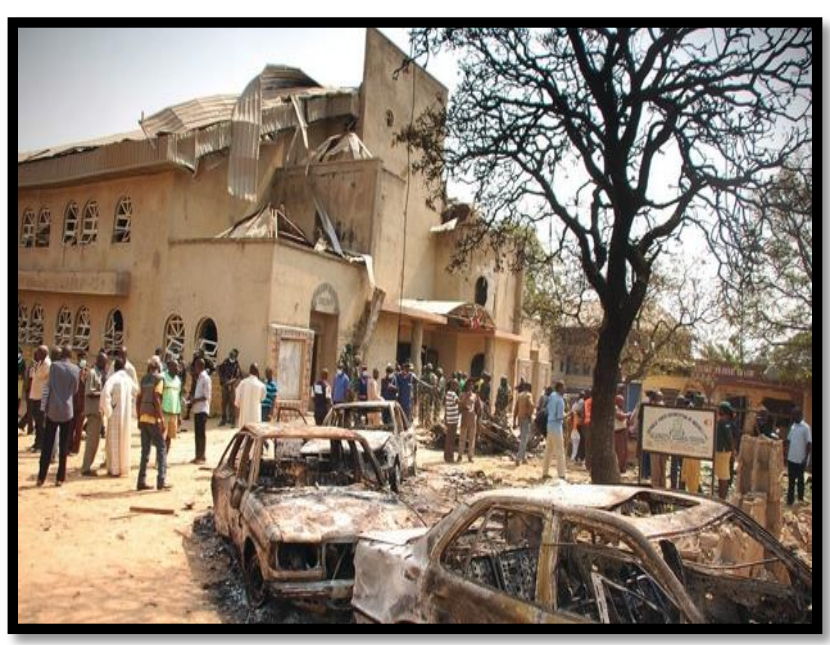

Plate 1: The bomb effect on the building of St Theresa Church at Madalla

Plates 1 shows St Theresa Catholic church at Madalla, Niger state which was bombed on $25^{\text {th }}$ December, 2011 (Christmas day). The plate gives a pictorial view of the effect of the explosion on the building and the vehicles. As observed there were no restrictions as to a clear car park, which led to the close range of parked cars to the building. Although a tree was within the premise, it is observed that this landscape element was not planted with the aim of deterring intrusion upon property and so was not used as a security measure.

\subsection{Physical Security Control Measures and Landscaping}

According to [24], to reduce the risks of direct contact and physical attacks against a facility, the physical security measures are mostly useful. These may occur in passive or active forms. Integrating protective measures in design minimizes the impact of mean attacks on a building immensely. The passive measures for a functioning security system according [25], is a permanent protective measure provided by both site and structure that involves the effective use of Engineering and Architecture to achieve improved security by eliminating potential security threats in public buildings. In other words, passive security measures are necessary in public buildings so as to eliminate potential security threats perpetrated by man-portable improvised explosive devices (MPIEDs) and vehicle-borne improvised explosive devices (VBIEDs).

According to the physical security design manual for VA facilities [26], passive measures are static elements such as static bollards, raised concrete planters, fences and trees of sufficient girth, standoff zone distance, integrated in the design from the inception stage. These are barriers that offer important benefits to physical security posture. They first and foremost create a psychological deterrent for anyone thinking of an unauthorized entry. Soft landscape can be used to soften and enhance the appearance of perimeter fences and other security elements [27]. They could also be used as perimeter fence in the form of thorny hedges and dense hedgerows. However, the application and choice of the soft landscape as a security measure, it is important to note that plantings must ensure they do not block important sight lines or create hiding places. In other words, plants near buildings should be high to keep sight lines open. Low planting adjacent to buildings may be admissible, but its height and density should not provide hiding places for people or packages or isolated areas that are not easily observed.

According to [28], natural surveillance could be considered as another physical security strategy. This is a major form of deterrence which can be incorporated into the design whereby the building spaces are more open and visible to security personnel and authorized users. This could be achieved by ensuring that dense tall vegetation are minimal or completely avoided. According to [29], consider lighting as another effective means of deterrence. Beyond that, in installing this security lighting system, it is important to place them in such a manner that they cannot be tampered with as well as provided with backups. In order to mitigate threat, it is imperative to introduce some basic preventive measures within and around the facility [30]. This preventive measures could include dense planting, trees, heavy objects, such as large sculptural objects, massive boulders, concrete forms with unassailable slopes can be used in a similar way to bollards to prevent vehicles from passing, while allowing the passage of pedestrians and bicycles. To ensure that such barriers can effectively reduce the threat level, engineering design and/or evaluation is necessary [31]. For example existing dense thickets of mature trees can be incorporated into a perimeter system. Landscape design uses a palette of living materials that respond to seasonal changes in climate and change in size and mass over time. The choice of appropriate plantings for the purpose of security is an important task. Plantings for security often suffer harsh environmental conditions like limited watering, compacted soils and runoff of chemicals from roads and sidewalks. These conditions are usually not healthy for plants and as such when a living landscape is installed with security function; it needs be well maintained to support its health and effectiveness.

\section{RESEARCH METHOD}

Data for the study was obtained using observation schedule purposefully structured to provide sufficient and relevant information for the analysis of the study. The paper is majorly aimed at providing information as

Vol. 36, No. 1, January 2017 
to the provision of landscape for climate adaptation as well as a means to mitigate the state of security in churches within Minna, Niger state in lieu of design implementations to improve them. The selection of the study sample was spread amongst Orthodox and Pentecostal churches within the 9 zones as regionalized by the Christian Association of Nigeria (CAN) using Stratified Random sampling method because not all the churches had their church building as many rented the place of worship. A total number of 54 churches were studied out of the 177 registered with the Christian Association of Nigeria (CAN) with 6 churches from each zone, evenly spread between the Orthodox and Pentecostal by studying 3 each at every zoneas shown in Table 2.Zones where the number of registered Pentecostal churches are not up to 3 , the Orthodox churches available was used to fill in so as to study 6 different church buildings within the zone. The elements that were observed include the type of soft landscape put in place by the church, the purpose of landscaping, presence of what bodies, the passive security elements put in place and landscape design in place. A questionnaire was administered to Architects who have been involved in building design and construction in Minna, they were selected at the monthly of the Nigerian Institute of Architects Minna chapter. They were required to rate select variables that related to landscaping and passive security of church building, a total of 59 architects participated in the study and their opinions were obtained using a Likert scale. The data from the observation survey and questionnaire was collated, sorted based on the zones and entered into the SPSS for analysis purposes while results are presented in tables and charts; pictures presented in plates to further buttress explanations within the result discussions.

Table 2: List of Studied Churches in Minna, Niger State

\begin{tabular}{|c|c|c|c|}
\hline S/No & Zone & Type of church & Name of church \\
\hline \multirow{2}{*}{1} & \multirow{2}{*}{ Minna Central West } & Orthodox & $\begin{array}{l}\text { St Michael catholic church } \\
\text { St Peter's Anglican cathedral } \\
1^{\text {st }} \text { ECWA church }\end{array}$ \\
\hline & & Pentecostal & $\begin{array}{l}\text { Redeemed Christian church of God } \\
\text { C \& S Headquarters } \\
\text { New Life for All }\end{array}$ \\
\hline \multirow[t]{2}{*}{2} & \multirow[t]{2}{*}{ Minna Central East } & Orthodox & $\begin{array}{l}\text { 1st Baptist church } \\
\text { St Andrew Anglican church } \\
\text { The Apostolic Church } \\
1^{\text {st }} \text { Gospel Baptist church }\end{array}$ \\
\hline & & Pentecostal & $\begin{array}{l}\text { Kingdom hall of Jehovah witness } \\
\text { The Living Word of Hope }\end{array}$ \\
\hline \multirow{2}{*}{3} & \multirow{2}{*}{ Tunga East } & Orthodox & $\begin{array}{l}5^{\text {th }} \text { ECWA church } \\
\text { COCIN church } \\
\text { Presbyterian church }\end{array}$ \\
\hline & & Pentecostal & $\begin{array}{l}\text { Living Faith } \\
\text { Foursquare Gospel church } \\
\text { The Lord's Chosen }\end{array}$ \\
\hline \multirow{2}{*}{4} & \multirow{2}{*}{ Tunga West } & Orthodox & $\begin{array}{l}\text { Our Lady of Fatima catholic church } \\
2^{\text {nd }} \text { ECWA Yoruba section } \\
\text { The Apostolic Church }\end{array}$ \\
\hline & & Pentecostal & $\begin{array}{l}\text { Ever Increasing Faith Bible church } \\
\text { Redeemed Christian church of God } \\
\text { The Redeemed Evang. Mission (TREM) }\end{array}$ \\
\hline \multirow{2}{*}{5} & \multirow{2}{*}{ Maitumbi } & Orthodox & $\begin{array}{l}\text { ECWA church } \\
\text { St John's catholic church } \\
\text { Christ Apostolic church }\end{array}$ \\
\hline & & Pentecostal & $\begin{array}{l}\text { Mountain of Fire and Miracles } \\
\text { Living Faith Church } \\
\text { Assembly of God }\end{array}$ \\
\hline \multirow{2}{*}{6} & \multirow{2}{*}{ Kpakungu } & Orthodox & $\begin{array}{l}\text { C \& S Ona-Iwa Mimo } \\
\text { Christ Apostolic church } \\
\text { St Mary's Catholic church }\end{array}$ \\
\hline & & Pentecostal & $\begin{array}{l}\text { Agape Love Chapel } \\
\text { Terbanacle of Mercy Chapel } \\
\text { Redeemed Church of God }\end{array}$ \\
\hline
\end{tabular}




\begin{tabular}{|c|c|c|c|}
\hline S/No & Zone & Type of church & Name of church \\
\hline \multirow{2}{*}{7} & \multirow{2}{*}{ Dutsen Kura } & Orthodox & $\begin{array}{l}\text { ECWA church } \\
\text { Sacred Heart Catholic Church } \\
\text { C \& S No. } 3\end{array}$ \\
\hline & & Pentecostal & $\begin{array}{l}\text { Redeemed Christian Church of God } \\
\text { Gospel faith mission } \\
\text { Deeper life }\end{array}$ \\
\hline \multirow{2}{*}{8} & \multirow{2}{*}{ Sauka Kahouta/ Barkin Sale } & Orthodox & $\begin{array}{l}\text { ECWA no. } 4 \\
\text { Covenant Baptist church } \\
\text { C.A.C Ile Anu }\end{array}$ \\
\hline & & Pentecostal & $\begin{array}{l}\text { Mountain of fire and miracles } \\
\text { Living Faith church } \\
\text { Deeper Life church }\end{array}$ \\
\hline \multirow[t]{2}{*}{9} & \multirow[t]{2}{*}{ Tayi village } & Orthodox & $\begin{array}{l}\text { C.A.C } \\
\text { Kauna Baptist church } \\
\text { COCIN } \\
\text { ECWA }\end{array}$ \\
\hline & & Pentecostal & $\begin{array}{l}\text { EYN church } \\
\text { Redeemed church }\end{array}$ \\
\hline
\end{tabular}

Table 3: Presence of Elevated Planters in the Studied Churches

\begin{tabular}{lcc}
\hline Church zone & \multicolumn{2}{c}{$\begin{array}{c}\text { Presence of elevated } \\
\text { planters }\end{array}$} \\
\cline { 2 - 3 } & Yes & No \\
\hline Minna Central West & 0 & 6 \\
Minna Cenral East & 0 & 6 \\
Tunga East & 0 & 6 \\
Tunga West & 0 & 6 \\
Maitumbi & 0 & 6 \\
Kpakungu & 0 & 6 \\
Dutsen Kura & 1 & 5 \\
Sauka Kahouta/Barkin & 0 & 6 \\
sale & & 6 \\
Tayi Village & 0 & 53 \\
Total & 1 & \\
\hline
\end{tabular}

Table 4: Type of Soft Landscape Provided

\begin{tabular}{lcccc}
\hline Church zone & \multicolumn{4}{c}{ Type of Soft Landscape Provided } \\
\cline { 2 - 5 } & Shrubs & Flowers & Trees & None \\
\hline Minna Central West & 0 & 1 & 2 & 3 \\
Minna Cenral East & 0 & 3 & 3 & 0 \\
Tunga East & 0 & 1 & 2 & 3 \\
Tunga West & 0 & 1 & 4 & 1 \\
Maitumbi & 0 & 1 & 0 & 5 \\
Kpakungu & 1 & 0 & 1 & 4 \\
Dutsen Kura & 0 & 0 & 2 & 4 \\
Sauka & 0 & 0 & 1 & 5 \\
Kahouta/Barkin sale & & & & \\
Tayi Village & 0 & 0 & 0 & 6 \\
Total & 1 & 7 & 15 & 31 \\
\hline
\end{tabular}

\section{FINDINGS AND DISCUSSION OF RESULTS}

The analysis of the data obtained through observation schedule was done and presented in tables and plates below. The churches were zoned for less cumbersome data presentation and analysing the soft landscape elements thereby seeking to address its adoption in churches within Minna as a security measure as well as a means to mitigate the climate change and its effect on man.

The result presented in Table 3 shows that a majority of the churches in Minna do not consider the use of elevated planters as an important security measure. This gives rise to an area which the Architect and the church administrator need to introduce to church designs as it can help as a security measure and at same time the plantings can help as an adaptive measure toward climate change in the country. Planters help to add to the beautification of the church and soften hard lines by helping to blend security into the overall site design. Soft landscapes can help to de-emphasize hardened security measures as seen in Plate 2 where RCCG Tunga West planted some flowers all in a bid to de-emphasize the presence of the "concrete-filled-drums" which are placed as security measures. Elevated planters are mostly used to direct traffic and in some cases do have reinforced bollards within them, thereby hindering vehicular access. Elevated planters can function as hardened security barriers. When reinforced and rightly placed, serve two purposes, providing both security and an attractive landscape element.

From Table 4, it can be deduced that 23 churches have soft landscape within the church premises while 31 churches do not which is approximately $57 \%$ of churches studied. Out of the $43 \%$ that have some soft landscape planted within the church premise, a very few were seen to have used these plants to direct traffic, restrict vehicular movement and deter intrusion while some others used it to soften the hard physical security elements. Most of the churches that planted soft landscape within were basically for beautification of the church as agreed by $[15,21]$. Credit should be given to churches like RCCG at Tunga West as seen in Plate 2 
having used soft landscape to soften the hard effect of bollards, amongst some other churches for having purposefully utilized soft landscape as security measures. St Michael Catholic Cathedral as seen in Plate 3 for using landscape elements to direct vehicular and pedestrian movement.

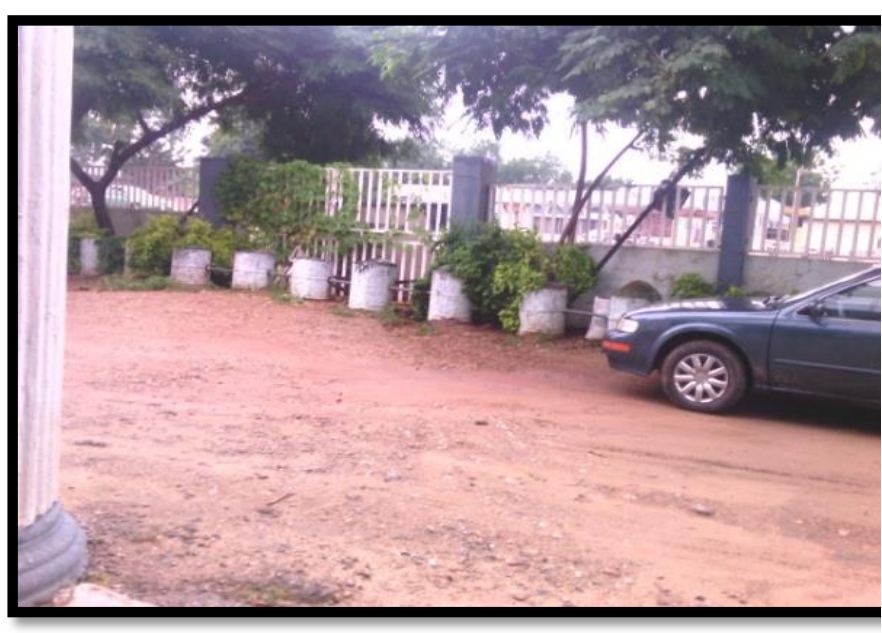

Plate2: RCCG at Tunga West showing use of soft landscape to soften and enhance the appearance of perimeter fences and other security elements.

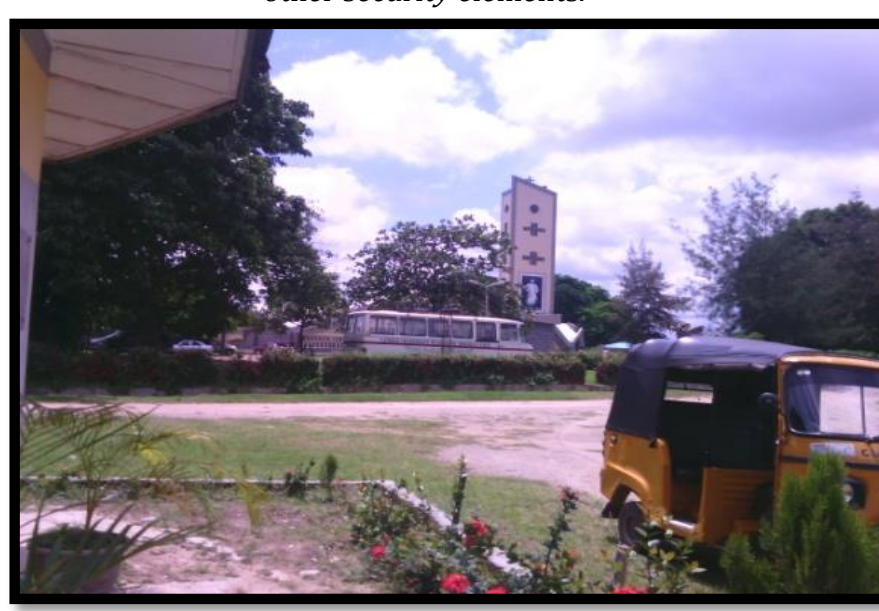

Plate 3: Soft landscape use to direct traffic within church site at St Michael Catholic Cathedral, Minna Central West.

\subsection{Security and Landscape Design in Churches}

Existing or carefully selected trees, plants, flowers are some of the soft landscape elements that can contribute to safety, comfort, traffic direction and restriction as against the case of St Theresa Catholic church shown in Plate 1 which didn't have plants restricting vehicle parking and direction of traffic. These landscape elements also add to the aesthetics of the environment as seen in plate 3 . By so doing, the plants which are also used for mitigating to climate change and it effects by their emission of oxygen into the atmosphere and intake of the $\mathrm{CO}_{2}$ which is excess in the air and causing ozone depletion.

Part of the consideration in the buildings' footprint in new churches construction, is the integration of the natural site characteristics with the placement of the building and the other site features such as the access roads, car park, walkways, and other public areas. Churches need to incorporate in the security design solutions natural environment to enhance the security and aesthetics. Landscaping that are environmentally sensitive, conserve resources, address social issues as well as proper blend of form and function to achieve a safe and sound structure that is aesthetically pleasing. This approach is considered to encourage environmental sustainability while it also addresses security challenges when properly handled by professionals as supported by $[14,32]$.

\subsection{Topography of Church Building Sites}

In some cases, nature provided helpful physical barriers which could have been adapted in the design, such as; natural barriers, topography, terrains and water bodies on site. These could be advantageous in the design of the churches, depending on how it is being embedded into the design by the architect. In the case of terrain, it could be of great advantage especially if it is rough, as it hinders vehicles from moving on speed thereby giving ample time for observation of vehicle borne with explosives. It was observed that Tayi village and Maitumbi are areas of natural rough terrain. In those areas most of the churches adapted to the terrain and topography while some other churches simply failed to take advantage of the landform. In Figure 1, it was observed that five, four churches in Maitumbi and Tayi village respectively adapted to the rough terrain of the site. It was also noted that in Minna central and Tunga zones were the topography was relatively flat hence they either had to create a manmade landform or simply provide barriers to act as security deterrence. The rough terrain of a site should be adapted when designing for security purpose and not just underplayed. The adaptation of the topography of the site in the building design of the churches should be of key importance because it would help with the visibility of intruders from afar, before they get into the church premises. This was evident in two churches (C.A.C and ECWA) located in Tayi, as the churches were located at the higher point of the land with access road at the lower part of the site. The advantage of building with the topography ensures that the natural environment is persevered to a large extent and hence runoff water can be controlled properly thereby reducing the risk of flooding that is caused from local actions of changing of water courses which is supported by $[27,32]$. 


\subsection{Rating of Landscaping for Passive Security and} Adaptation to Climate

In examining the adequacy of the landscaping elements for passive security and adaptation to climate change there was need to determine the opinion of architects involved building designs to determine the adequacy of the variables using a Likert Scale measurement calculation.

\section{Likert Scale Measurement}

The weighted score of 1 to 4 was allocated to the rating options of adequacy based on the perception of the respondents regarding the variable measured;

Very Adequate $\quad 1$

Adequate 2

Inadequate 3

Very Inadequate 4

It could be observed from Table 5 that variables that had to do with landscape design such as curvilinear concept, use of speed breakers and provision of garden lights appear to have more respondents considering them as either adequate or very adequate. The use of climbers on the building was considered inadequate and this was due to the fact that it could hinder visual contact of the exterior from the interior space even though it would have improved the adaptation of the building to climate changes by reducing the amount of heat gain by the building. Table 6 is a representation of the multiplication of the variable score with the assigned values which was used to generate Table 7 upon which the final determination on each variable is made.

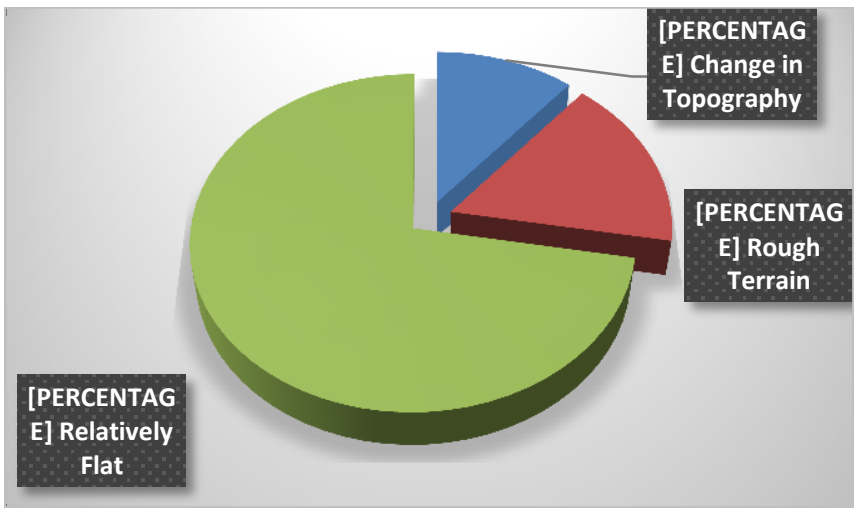

Figure 1:Topography of church building Sites

Table 5: Number of Respondents per Opinion on Landscaping for Passive Security and Adaptation to Climate in Church Environment

\begin{tabular}{|c|c|c|c|c|c|}
\hline Measured Variable & $\begin{array}{c}\text { Very } \\
\text { Adequate }\end{array}$ & Adequate & Inadequate & $\begin{array}{c}\text { Very } \\
\text { Inadequate }\end{array}$ & Total \\
\hline Curvilinear concept in design of landscape improves security. & 5 & 36 & 11 & 7 & 59 \\
\hline Use of masquerade along fence improves security. & 2 & 18 & 23 & 13 & 56 \\
\hline $\begin{array}{l}\text { Placement of hedges along the driveway within church } \\
\text { improves security. }\end{array}$ & 7 & 32 & 14 & 5 & 58 \\
\hline $\begin{array}{l}\text { The use of speed breakers along driveway improves church } \\
\text { security. }\end{array}$ & 16 & 27 & 9 & 7 & 59 \\
\hline The use of flower climbers on the building improves security. & 0 & 16 & 31 & 11 & 58 \\
\hline $\begin{array}{l}\text { The provision of water bodies around the church premises } \\
\text { improves the security. }\end{array}$ & 2 & 15 & 21 & 19 & 57 \\
\hline The provision of garden light lights at lawns. & 10 & 34 & 8 & 7 & 59 \\
\hline The uses of elevated planters on church buildings. & 5 & 29 & 17 & 8 & 59 \\
\hline The location of the car park away from building. & 27 & 19 & 8 & 2 & 56 \\
\hline The use of boulders between car park and church buildings. & 12 & 35 & 11 & 0 & 58 \\
\hline The provision of open lawn before church building. & 4 & 19 & 24 & 12 & 59 \\
\hline The provision of lawn chairs in the open spaces for seating. & 0 & 12 & 31 & 14 & 57 \\
\hline Provision of direct drive from entrance gate to church building. & 0 & 9 & 17 & 32 & 58 \\
\hline The of gravel finish for driveway within church & 8 & 29 & 14 & 7 & 58 \\
\hline $\begin{array}{l}\text { The provision of picket fence around the church covered with } \\
\text { climbers }\end{array}$ & 18 & 21 & 15 & 4 & 58 \\
\hline The provision of man-made hills within the church premises. & 3 & 15 & 29 & 11 & 58 \\
\hline Provision of dedicated walks along the lawns and driveways. & 15 & 23 & 17 & 4 & 59 \\
\hline
\end{tabular}

Table 6: Sum of respondents' responses on Opinion on Landscaping for Passive Security and Adaptation to Climate in Church Environment

\begin{tabular}{|c|c|c|c|c|c|}
\hline Measured Variable & $\begin{array}{l}\text { Very Adequate } \\
\text { (X1) }\end{array}$ & $\begin{array}{l}\text { Adequate } \\
\text { (X2) }\end{array}$ & $\begin{array}{c}\text { Inadequate } \\
(3)\end{array}$ & $\begin{array}{c}\text { Very Inadequate } \\
(4) \\
\end{array}$ & Sum \\
\hline $\begin{array}{l}\text { Curvilinear concept in design of landscape improves } \\
\text { security. }\end{array}$ & 5 & 72 & 33 & 28 & 138 \\
\hline Use of masquerade along fence improves security. & 2 & 36 & 69 & 52 & 159 \\
\hline $\begin{array}{l}\text { Placement of hedges along the driveway within } \\
\text { church improves security. }\end{array}$ & 7 & 64 & 42 & 20 & 133 \\
\hline
\end{tabular}




\begin{tabular}{|c|c|c|c|c|c|}
\hline Measured Variable & $\begin{array}{l}\text { Very Adequate } \\
\text { (X1) } \\
\end{array}$ & $\begin{array}{l}\text { Adequate } \\
(\mathrm{X} 2)\end{array}$ & $\begin{array}{l}\text { Inadequate } \\
(3)\end{array}$ & $\begin{array}{l}\text { Very Inadequate } \\
(4)\end{array}$ & Sum \\
\hline $\begin{array}{l}\text { The use of speed breakers along driveway improves } \\
\text { church security. }\end{array}$ & 16 & 54 & 27 & 28 & 125 \\
\hline $\begin{array}{l}\text { The use of flower climbers on the building improves } \\
\text { security. }\end{array}$ & 0 & 32 & 93 & 44 & 169 \\
\hline $\begin{array}{l}\text { The provision of water bodies around the church } \\
\text { premises improves the security. }\end{array}$ & 2 & 30 & 63 & 76 & 171 \\
\hline The provision of garden light lights at lawns. & 10 & 68 & 24 & 28 & 130 \\
\hline The uses of elevated planters on church buildings. & 5 & 58 & 51 & 32 & 146 \\
\hline The location of the car park away from building. & 27 & 38 & 24 & 8 & 97 \\
\hline $\begin{array}{l}\text { The use of boulders between car park and church } \\
\text { buildings. }\end{array}$ & 12 & 70 & 33 & 0 & 115 \\
\hline The provision of open lawn before church building. & 4 & 38 & 72 & 48 & 162 \\
\hline $\begin{array}{l}\text { The provision of lawn chairs in the open spaces for } \\
\text { seating. }\end{array}$ & 0 & 24 & 93 & 56 & 173 \\
\hline $\begin{array}{l}\text { Provision of direct drive from entrance gate to } \\
\text { church building. }\end{array}$ & 0 & 18 & 51 & 128 & 197 \\
\hline The of gravel finish for driveway within church & 8 & 58 & 42 & 28 & 136 \\
\hline $\begin{array}{l}\text { The provision of picket fence around the church } \\
\text { covered with climbers }\end{array}$ & 18 & 42 & 45 & 16 & 121 \\
\hline $\begin{array}{l}\text { The provision of man-made hills within the church } \\
\text { premises. }\end{array}$ & 3 & 30 & 87 & 44 & 164 \\
\hline $\begin{array}{l}\text { Provision of dedicated walks along the lawns and } \\
\text { driveways. }\end{array}$ & 15 & 46 & 51 & 16 & 128 \\
\hline
\end{tabular}

Table 7: Respondents' opinion on adequacy of Landscaping for Passive Security and Adaptation to Climate in Church Environment

\begin{tabular}{|c|c|c|c|c|}
\hline Measured Variable & Sum & Mean & Interpretation & Rank \\
\hline $\begin{array}{l}\text { Curvilinear concept in design of landscape improves } \\
\text { security. }\end{array}$ & 138 & 2.338983 & Adequate & 8th \\
\hline Use of masquerade along fence improves security. & 159 & 2.839286 & Inadequate & $13^{\text {th }}$ \\
\hline $\begin{array}{l}\text { Placement of hedges along the driveway within church } \\
\text { improves security. }\end{array}$ & 133 & 2.293103 & Adequate & 7th \\
\hline $\begin{array}{l}\text { The use of speed breakers along driveway improves } \\
\text { church security. }\end{array}$ & 125 & 2.118644 & Adequate & $4^{\text {th }}$ \\
\hline $\begin{array}{l}\text { The use of flower climbers on the building improves } \\
\text { security. }\end{array}$ & 169 & 2.913793 & Inadequate & $14^{\text {th }}$ \\
\hline $\begin{array}{l}\text { The provision of water bodies around the church } \\
\text { premises improves the security. }\end{array}$ & 171 & 3.000000 & Inadequate & $15^{\text {th }}$ \\
\hline The provision of garden light lights at lawns. & 130 & 2.203389 & Adequate & $6^{\text {th }}$ \\
\hline The uses of elevated planters on church buildings. & 146 & 2.474576 & Adequate & $10^{\text {th }}$ \\
\hline The location of the car park away from building. & 97 & 1.732143 & Adequate & $1^{\text {st }}$ \\
\hline $\begin{array}{l}\text { The use of boulders between car park and church } \\
\text { buildings. }\end{array}$ & 115 & 1.982759 & Adequate & $2^{\text {nd }}$ \\
\hline The provision of open lawn before church building. & 162 & 2.745763 & Inadequate & $11^{\text {th }}$ \\
\hline $\begin{array}{l}\text { The provision of lawn chairs in the open spaces for } \\
\text { seating. }\end{array}$ & 173 & 3.035088 & Inadequate & $16^{\text {th }}$ \\
\hline $\begin{array}{l}\text { Provision of direct drive from entrance gate to church } \\
\text { building. }\end{array}$ & 197 & 3.396552 & Inadequate & $17^{\text {th }}$ \\
\hline The of gravel finish for driveway within church & 136 & 2.344828 & Adequate & $9^{\text {th }}$ \\
\hline $\begin{array}{l}\text { The provision of picket fence around the church } \\
\text { covered with climbers }\end{array}$ & 121 & 2.086207 & Adequate & $3^{\text {rd }}$ \\
\hline $\begin{array}{l}\text { The provision of man-made hills within the church } \\
\text { premises. }\end{array}$ & 164 & 2.827586 & Inadequate & 12th \\
\hline $\begin{array}{l}\text { Provision of dedicated walks along the lawns and } \\
\text { driveways. }\end{array}$ & 128 & 2.169492 & Adequate & $5^{\text {th }}$ \\
\hline
\end{tabular}

In interpreting the results from the Likert scale calculation, a range of scale measurement was agreed as indicated:
$1.0 \quad-$
1.49
Very Adequate
$1.5 \quad-\quad 2.49$
Adequate
$2.5-$
3.49
Inadequate
$>\quad 3.5$
Very Inadequate

In determining the adequacy of the option for each measured variable the weighted score was divided by the number of valid respondents for each section and the 
value is presented against it as shown in Table 7. It could be observed that of the seventeen variables that related to landscaping measured ten of them were consider as adequate in meeting the demand to improve security of church buildings using passive methods in designing. The variables were further ranked and it could be observed from the ranking the variables that ranked between one and ten were issues that could easily be tackled at the design and construction stages of the church building and they did not hinder the movement of the worshippers nor the impaired their visuals while at the church premises which is in accordance to [32, 34]. The provision of chairs within the lawn ranked $16^{\text {th }}$ it could be understood that there was need to avoid creating avenues for people to loiter around the church premises which could allow for hiding of explosive items under such seats which agrees with [33]. The implication of these findings is that architects involved in the design of church buildings or landscaping of church premises could understand how to approach issues related to security as it affects the landscaping of the premises.

\section{CONCLUSION}

From the data analysed above, it can be concluded that most of the churches in Minna, Niger state do not fully employ soft landscape as a security design measure and as a result do not help in the adaptation to climate change as well as being prone to the attacks of intruders. The issue of landscaping cuts across soft and hard landscape elements and these have effect on the environment and climate of the area. The issue of security in churches particularly in the northern part of Nigeria has become great challenge to everyone, given the rate of attacks on them. The challenge for the architects and professionals had always been to seek out new ways of ensuring that the risk of attacks and the effects on the building and its occupants can be reduced. In merging these two issues the study examined how passive security of church buildings could be improved with landscaping while also ensuring that the climate of the region was adapted to. The study observed that the use selected landscape elements were basically used for aesthetic values and not for improvement of security. The natural features offered by the landforms and topography were ignored in the design of many churches with many opting for flat ground. The need for blend of the passive security and landscaping was examined amongst the architects and the result showed that it was possible to achieve the goal given the rating of the variables presented in Table 7 . The use of concrete materials should be greatly reduced as the effect of temperature gain was affecting the buildings which required more cooling than expected. It is safe to conclude that the need for integration of passive security measures in the designs of churches can be achieved if the architects involved place a premium value on this aspect of their design. The passive nature of the security features will ensure that these provisions are not easily spotted by prospective intruders and it would also not pose a challenge for the daily worshippers.

\section{REFERENCES}

[1] Adeleke, K. Climate Change in Architecture and the National Development Agenda III. Seminar. 2008.

[2] Atilola, 0. Climate Change and the Environment: Issues and Geo-Information Challenges. Knowing To Manage The Territory, Protecting The Environment, Evaluate The Cultural Heritage. Rome, Italy, 6-10 May 2012

[3] Intergovernmental Panel on Climate Change, First Assessment Report. UNEP: IPCC (2007): Climate Change 2007; The Scientific Basis: Contribution of Working Group I To The Third Assessment Report Of The Intergovernmental Panel On Climate Change Cambridge University Press. 2007.

[4] Barnet, J. \& Adger, W. Climate change, human security and violent Conflict. Geographical journal on Climate change. 27(3), 36-47. 2007.

[5] Oni, O. F, \& Akingbohungbe, O. D. Climate Change and Architectural Practice in Nigeria. Journal of Environment and Earth Science. 3(4), 72-81. 2013.

[6] Amadu, I. M. Education and Nationalism in Nigeria: A Religious Perspective. Religion and State: The Experience, Ibadan Gilbert, Grace and Gabriel Association. 1989.

[7] UN Habitat, Cities and Climate Change: Global Report on Human Settlements 2011. United Nations Human Settlements Program. 2011.

[8] Beland, D. The Political Construction of Collective Insecurity: From Moral Panic to Blame Avoidance and Organized Irresponsibility. Centre for European Studies, Working Paper Series 126. 2005.

[9] Achumba, I. C., Ighomereho, O. S., \& Akpan-Robaro, M. O. M. Security Challenges in Nigeria and the Implications for Business Activities and Sustainable Development. Journal of Economics and Sustainable Development, 4(2), 79-99. 2013.

[10] Ibrahim, A. M. \& Azubuike, A. S. A Review on the Security Challenges in Northern Nigeria and its Implications for Business Survival and Sustainable Development. Journal of Management and Corporate Governance, 6(2), 46 - 54. 2014.

[11] Olaniyi, O. A, Funmilayo, O. A. \& Olutimehin, I. 0. Review of climate change and its effect on Nigeria ecosystem. International Journal of Environment and Pollution Research 2(3), 70-81. 2014. 
[12] Odjugo, P. A. O. General Overview of Climate Change in Nigeria. Journal of Geography and Regional planning, 3(6), 26-36. 2010.

[13] Fatile, J. 0. \& Adejobi, 0. S. Climate Change, Environment and Conflicts in Nigeria. British Journal of Arts and Social Sciences ISSN: 20469578, 6(1), 56-67. 2012.

[14] Adeleke, 0. 0. Mitigating the Effects of Climate Change through Sustainable Building Environment Agenda IV. Seminar Proceedings Organized By Architects Registration Council Of Nigeria, April, 2011.

[15] Ezeabasili, A. C. C. \& Okonkwo, A. U Climate change impacts on the built environment in Nigeria. African research review. An International Multidisciplinary Journal Ethiopa. 7(4), 288-303. doi: http://dx.doi.org/10.4314/afrrev.7i4.18. 2013.

[16] Martin, C., Campillo, G., Meirovich, H. \& Navarrete, J. Climate Change Mitigation \& Adaptation through Publically-Assisted Housing: Theoretical Framework for the IDB's Regional Policy Dialogue on Climate Change. Inter-American Development Bank. Technical note no. Idb-tn-593. 2013.

[17] Sampson, I. T. \& Onuoha, F. C. Forcing the Horse to Drink or Making it Realise its Thirst? Understanding the Enactment of Anti-Terrorism Legislation (ATL) in Nigeria. Perspectives on Terrorism, 5(3-4). 2011.

[18] Ushe, M. U. Religious conflicts and education in Nigeria: Implications for national security, International Journal of Educational Research and Development, 1(2), 011-022. 2012.

[19] Hammar, R. Does Your Church Need a Security Guard? Church Law and Tax Report March/April 2008, 1-12. 2008.

[20] Azazi, A., "Responding to the Emerging Trends of Terrorism in Nigeria", $5^{\text {th }}$ Policing Executive Forum Conference Proceedings Organized by CLEEN Foundation. Lagos. 2011.

[21] Brian, M. \& Harrell, C. P. P. Security Challenges for Houses of Worship. Journal of Physical Security 4(2), 1-9; North American Electric Reliability Corporation (NERC). 2010.

[22] Ewetan, 0. 0. \& Urhie E. Insecurity and SocioEconomic Development in Nigeria. Journal of Sustainable Development Studies. 5(1), 40-63 2014.
[23] Fennelly, L. J. Protective Barriers. Retrieved from http://www.sciencedirect.com/science/article/pii/ B9780124158924000055 2013.

[24] Department of Homeland Security, Guarding Against Terrorism and Ensuring Transportation Security. Retrieved from https://www.dhs.gov/xlibrary/assets/9-11commission-update-report-7-22-10.pdf 2010.

[25] National Capital Planning Commission. The National Capital Urban Design and Security Plan. Washington, DC. 2002.

[26] Physical Security Design Manual for VA Facilities, Life Safety Protected Facilities. Department of Veterans Affairs, Washington, DC 20420. 2007.

[27] FEMA, Site and Urban Design for Security. Guidance against Potential Terrorist Attacks. U.S Department of Homeland Security. 2007.

[28] Talbot, Julian \& Jakeman, M. Security Risk Management Body of Knowledge doi: http://books.google.com/books?id=5xAhp9B1264 C\&pg=PT73. 2011.

[29] Kovacich, G. L. \& Halibozek, E. P. The Manager's Handbook for Corporate Security: Establishing and Managing a Successful Assets Protection Program. New York: Butterworth-Heinemann. 2003.

[30] Winstead, D. L. The Site Security Design Guide. U.S. General Services Administration Public Buildings Service. Washington DC. 2007.

[31] http://ww38.securitrus.com/documents/ FEMAPerimeterSecurityDesign.pdf?

[32] Whole Building Design Guide. National Institute of Building Sciences: Landscape Architecture and the Site Security Design Process. Excerpted from Security Design and the Landscape Architect. USA: Landscape Architecture Technical Information Series (LATIS) publication 2014.

[33 Rowe, T. L. Church Security: How to Access the Safety and Security of your Place of Worship. Retrieved from http://tinalewisrowe.com/ category/safety-andsecurity/the-greeter-andusher-role/ 2009.

[34] Crowe, T. Crime Prevention through Environmental Design: Applications of Architectural Design and Space Management Concepts (2nd ed.). Woburn, Massachusetts: Butterworth-Heinemann. 2000. 